\title{
Edukasi Pengembangan Budidaya Alpokat pada Kelompok Tani Rukun Makaryo Desa Pereng, Mojogedang, Karanganyar
}

\author{
Putri Permatasari $^{1 *}$, Joko Winarno ${ }^{1}$, Suwarto $^{1}$, Sapja Anantanyu ${ }^{1}$, Agung Wibowo ${ }^{1}$, \\ Suryono ${ }^{2}$ \\ ${ }^{1}$ Program Studi Penyuluhan dan Komunikasi Pertanian Fakultas Pertanian UNS \\ ${ }^{2}$ Program Studi Ilmu Tanah Fakultas Pertanian UNS \\ *Correspoding Author : putripermatasari@staff.uns.ac.id
}

\begin{abstract}
ABSTRAK
Penyuluhan merupakan proses penyebarluasan informasi agar terjadi perubahan perilaku menjadi tahu, mau, dan mampu dalam melakukan usahatani demi peningkatan produktivitas, pendapatan, serta, perbaikan kesejahteraan petani beserta keluarganya. Kegiatan penyuluhan dilakukan pada Kelompok Tani Rukun Makaryo Dusun Dani, Desa Pereng, Kecamatan Mojogedang yang telah menerapkan One Village One Product (OVOP) buah alpokat. Kegiatan penyuluhan bertujuan untuk meningkatkan kemampuan Kelompok Tani Rukun Makaryo dalam melakukan budidaya alpokat sehingga produktivitas meningkat dan menambah pendapatan masyarakat. Metode dan teknik penyuluhan dilakukan secara kelompok dengan demonstrasi cara, diskusi, dan pemutaran video prospek budidaya alpokat. Demonstrasi cara dapat memberikan gambaran yang lebih jelas mengenai pembiakan vegetatif dengan teknik sambung pucuk dan pembuatan biostarter untuk mempercepat proses fermentasi limbah padat ternak sapi. Kegiatan diskusi dapat memunculkan interaksi dengan petani sehingga petani berpartisipasi aktif dan mampu membantu memecahkan permasalahan yang dihadapi saat ini. Pemutaran video mengenai teknik budidaya alpokat membantu meyakinkan kelompok tani karena dapat menyaksikan secara langsung keberhasilan budidaya alpokat yang dilakukan dengan teknik yang tepat. Kegiatan pengabdian yang dilakukan dengan penyuluhan mampu mengubah pengetahuan, sikap, dan keterampilan petani dalam melakukan budidaya alpokat. Pengetahuan dan keterampilan petani bertambah terutama dalam teknik sambung pucuk dan pembuatan biostarter. Petani dapat membuat pupuk organik dengan memanfaatkan kotoran ternak yang banyak tersedia di sekitar rumah penduduk. Sikap petani juga mengalami perubahan, hal tersebut terlihat pada penggunaan pupuk organik padat oleh petani pada budidaya alpukat. Penggunaan pupuk organik padat mampu mengurangi biaya produksi dan meningkatkan pendapatan.
\end{abstract}

Kata kunci: penyuluhan, budidaya alpokat, kelompok tani

\section{ABSTRACT}

Extension is a process of disseminating information so that there is a change in behavior to become aware, willing and able to do farming for the sake of increasing productivity, income, improving the welfare of farmers and their families. The counseling activity was carried out at the Rukun Makaryo farmer group in Dani Village Pereng Mojogedang who had implemented One Village One Product (OVOP) avocado fruit. The extension activity aims to increase the ability of the Rukun Makaryo farmer group to cultivate avocado fruit so that increases productivity and community income. Extension methods and techniques were carried out in groups with demonstrations, discussions and video screenings of the prospect of avocado cultivation. Demonstrations of how to provide a clearer picture of vegetative propagation by shoot grafting and biostarter production to accelerate the fermentation process of solid waste from cattle. Discussion activities can lead to interaction cattle. Discussion activities can lead to interaction with farmers so that they participate actively and are able to help solve problems faced at this time. Screening videos of avocado cultivation techniques helped convince farmer groups because they could witness firsthand the success of avocado cultivation carried out with the right technique. Community service activities carried out through counseling are able to change the knowledge, attitudes and skills of farmers in cultivating avocado fruit. Farmers knowledge and skills have increased, especially in shoot grafting and biostarter production. Farmers can make organic fertilizers by using manure that is widely available around people's homes. The attitude of farmers has changed by using solid organic fertilizers in avocado cultivation. The use of solid organic fertilizer can reduce production costs and increase income.

Keywords : extention, avocado cultivation, farmer groups 


\section{PENDAHULUAN}

Kelompok Tani Rukun Makaryo merupakan kelompok tani yang berlokasi di Dusun Dani, Desa Pereng, Kecamatan Mojogedang yang sejak tahun 2000 telah menerapkan sistem pertanian organik pada hamparan tanaman padi. Atas prestasinya dalam melakukan sosialisasi dan penerapan sistem pertanian organik, maka pada tahun 2008 Kelompok Tani Rukun Makaryo dikukuhkan oleh Bupati Karanganyar sebagai perintis kelompok tani organik. Komoditas utama yang ditanam adalah padi organik, namun pada lahan pekarangan, kelompok tani juga membudidayakan alpokat sebagai komoditas sampingan sehingga dapat menambah pendapatan keluarga. Budidaya alpokat yang dilakukan belum sepenuhnya menggunakan teknik yang tepat, baik dari persiapan bibit, penanaman, pemeliharaan tanaman, hingga pengendalian hama dan penyakit. Bahkan terkadang saat tanaman masih muda terdapat beberapa tanaman yang mati karena penyiraman secara berlebihan (sampai tergenang). Penggunaan dosis pupuk kimia yang tidak tepat dapat menyebabkan tanaman layu dan mengalami pertumbuhan tidak optimal. Pada masa pertumbuhan vegetatif, tanaman alpokat lebih membutuhkan unsur Nitrogen, sedangkan pada masa generatif atau pembuahan tanaman membutuhkan lebih banyak unsur Phospor dan Kalium. Anggota Kelompok Tani Rukun Makaryo telah terbiasa membuat pupuk organik, namun belum diaplikasikan pada tanaman alpokat. Padahal dengan penggunaan pupuk organik banyak manfaat yang dapat dirasakan antara lain memperbaiki kesuburan dan struktur tanah.

Penyuluhan mengenai teknik budidaya alpokat dilakukan dalam rangka memberikan informasi agar terjadi perubahan sikap, pengetahuan, dan keterampilan. Petani pada awalnya hanya menggunakan pupuk organik untuk tanaman padi, sehingga diharapkan dengan adanya edukasi ini maka penggunaan pupuk organik dapat diterapkan juga pada budidaya alpokat. Anggota kelompok tani banyak yang belum mengetahui teknik sambung pucuk dan cara pembuatan biostarter. Penyampaian inovasi teknologi yang dilakukan diharapkan dapat meningkatkan pengetahuan pada peserta. Penyuluhan dapat membentuk kemandirian petani dalam upaya meningkatkan kesejahteraan hidupnya (Sadono, 2008).
Penyuluhan mempunyai prinsip kemandirian dalam upaya mengubah perilaku masyarakat agar dapat berkembang secara mandiri yang dilakukan melalui pendidikan non formal untuk menyelesaikan suatu masalah (Amanah, 2007). Dengan adanya kegiatan penyuluhan diharapkan petani dapat menerapkan inovasi teknologi yang ditawarkan sehingga pendapatan dan kesejahteraannya meningkat.

Kegiatan edukasi dilakukan dengan penyuluhan menggunakan metode dan teknik secara kelompok melalui demonstrasi cara, diskusi dan pemutaran video prospek budidaya alpokat. Tanaman buah alpokat unggul berumur 3 tahun apabila dibudidayakan dengan baik dapat menghasilkan buah alpokat minimal 30 $\mathrm{kg}$ setiap pohonnya. Tanaman buah alpokat varietas unggul yang dibudidayakan dengan baik dapat menjadi aset yang bernilai ekonomi bagi pemiliknya. Kegiatan pengabdian berupa penyuluhan pertanian dalam pengembangan budidaya alpokat pada Kelompok Tani Rukun Makaryo bertujuan untuk meningkatkan produktivitas dan pendapatan masyarakat yang diperoleh dengan budidaya secara tepat. Kegiatan ini dapat meningkatkan kapasitas petani melalui peningkatan pengetahuan dan keterampilan. Proses adopsi suatu inovasi dilakukan dengan peningkatan pengetahuan dan diseminasi inovasi teknologi sehingga dapat mengubah sikap serta memperbaiki keterampilan petani.

\section{METODE}

Kegiatan pengabdian diawali melakukan koordinasi dengan ketua kelompok tani untuk membahas mekanisme pelaksanaan penyuluhan serta identifikasi kebutuhan anggota. Pelaksanaan penyuluhan dilakukan dengan mengundang 40 anggota kelompok tani Rukun Makaryo. Kegiatan identifikasi kebutuhan bertujuan untuk mengetahui masalah yang dialami selama melakukan budidaya alpokat dan menentukan materi penyuluhan yang akan disampaikan. Materi penyuluhan disesuaikan kebutuhan dari peserta pelatihan sehingga pendapatan dan produksi meningkat serta dapat membantu memecahkan permasalahan yang sedang terjadi (Setiana, 2005). Kegiatan identifikasi kebutuhan pada kelompok tani dilaksanakan tanggal 23 Juni 2020 yang disajikan pada Gambar 1.

Kegiatan pengabdian masyarakat dilaksanakan tanggal 11 Agustus 2020 yang 
dihadiri 30 anggota kelompok tani. Metode kegiatan pengabdian masyarakat ini dilakukan melalui penyuluhan secara kelompok dengan melibatkan seluruh peserta yang hadir. Kegiatan yang dilakukan secara berkelompok sangat dinilai efektif karena pemberian bimbingan pada kelompok akan lebih mudah dilakukan dan kerjasama akan lebih terjalin (Alviana et al., 2019). Fungsi kelompok antara lain sebagai tempat untuk kegiatan pembelajaran dan kerjasama (Utama et al., 2010). Penyuluhan secara kelompok diawali dengan sosialisasi teknik budidaya alpokat sehingga dapat memperkenalkan dan memberikan informasi mengenai teknik budidaya alpokat secara tepat. Agar lebih meningkatkan keyakinan anggota kelompok tani maka penyuluhan didukung dengan teknik pemutaran video prospek budidaya alpokat oleh pengusaha yang sudah berhasil. Bahan pembelajaran berupa audio visual yang terdapat pada video sangat bermanfaat dalam pesan yang disampaikan (Ainina, 2014). Dengan teknologi komunikasi berupa handphone android yang sudah banyak dimiliki oleh anggota kelompok tani maka dapat menunjang dalam penyebarluasan informasi mengenai prospek berkebun alpokat tersebut. Melalui pendekatan ini diharapkan setiap anggota dapat meningkatkan pemahaman tentang cara budidaya alpokat bibit unggul.

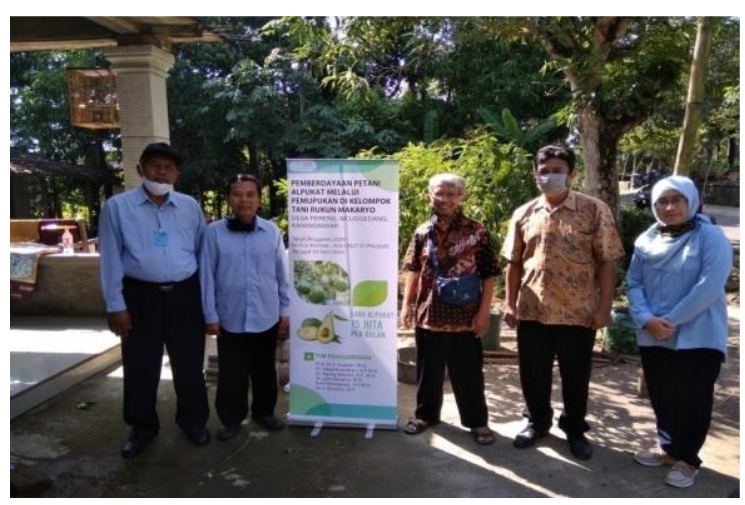

Gambar 1. Koordinasi Team Pengabdian dengan Ketua Kelompok Tani Rukun Makaryo

Kegiatan kemudian dilanjutkan dengan demonstrasi cara budidaya alpokat yang meliputi perbanyakan vegetatif dengan sambung pucuk (top grafting) serta pembuatan biostarter untuk mempercepat proses fermentasi limbah padat ternak sapi. Demonstrasi cara dilakukan untuk memperlihatkan cara melakukan sesuatu setahap demi setahap. Teknik demonstrasi cara dapat meningkatkan motivasi bagi peserta. Motivasi dapat lebih meningkatkan semangat dari peserta untuk mengikuti kegiatan sesuai tujuan (Yunasaf \& Tasripin, 2011). Kegiatan diakhiri dengan diskusi yang dilakukan dengan anggota Kelompok Tani Rukun Makaryo. Proses komunikasi dialog interpersonal akan menciptakan kesetaraan antara kedua belah pihak yang berdiskusi (Muchtar et al., 2014). Diskusi yang dilakukan dengan negosiasi secara bersama lebih baik daripada keputusan yang diambil secara sepihak. Kegiatan ini menciptakan interaksi antar anggota kelompok untuk saling bertukar pengalaman serta lebih meningkatkan partisipasi kelompok tani dalam melakukan budidaya alpokat secara tepat.

Edukasi yang diberikan kepada Kelompok Tani Rukun Makaryo melalui penyuluhan, demonstrasi cara, pemutaran video serta diskusi melibatkan seluruh peserta sehingga diharapkan dapat menerapkan cara budidaya alpokat secara tepat dengan perbanyakan vegetatif sambung pucuk (top grafting), pembuatan biostarter untuk mempercepat proses fermentasi limbah padat ternak sapi, dan penggunaan pupuk organik pada budidaya alpokat. Kegiatan monitoring dilakukan setelah pemberian edukasi disertai dengan pendampingan pada anggota kelompok. Keberhasilan kegiatan dinilai dengan cara membandingkan kondisi sebelum dan sesudah pelatihan melalui observasi lapangan pada 30 lahan petani peserta pelatihan.

\section{HASIL DAN PEMBAHASAN}

Anggota Kelompok Tani Rukun Makaryo telah menerapkan One Village One Product (OVOP) buah alpokat. Budidaya alpokat mempunyai nilai ekonomi sehingga dapat menambah pendapatan masyarakat. Buah alpokat biasanya dijual dengan harga $\mathrm{Rp}$ $25.000,00 / \mathrm{kg}$ - Rp 40.000,00/kg. Anggota Kelompok Tani Rukun Makaryo lebih sering membudidayakan alpokat jenis mentega. Alpokat mentega memiliki ciri bentuknya bulat, buah yang masih muda berwarna hijau tua, sedangkan buah tua berwarna hijau tetapi lebih muda dan agak kusam (Anova \& Kamsina, 2013). Kandungan tanin, alkaloid, flavonoid, triterpenoid dan saporin terdapat dalam alpokat mentega (Malangngi et al., 2012). Dengan memperhatikan pengalaman masyarakat yang telah lama melakukan budidaya alpokat dan adanya sumber bahan baku lainnya seperti ketersediaan pupuk organik dalam jumlah 
melimpah, maka produktivitas masih dapat ditingkatkan. Dengan usaha penerapan budidaya secara tepat maka dapat meningkatkan produktivitas.

Proporsi daging buah, biji dan kulit alpokat ditentukan oleh varietas, cara budidaya, kondisi tumbuh, dan faktor-faktor lingkungan (Araújo et al., 2018). Oleh karena itu, cara budidaya seperti teknik perbanyakan tanaman juga harus diperhatikan. Teknik perbanyakan tanaman dapat dilakukan dengan pembiakan vegetatif sehingga dapat menghasilkan bibit yang mempunyai sifat sama dengan induknya serta lebih cepat berbuah. Perbanyakan vegetatif yang dapat diterapkan antara lain setek, cangkok, sambung pucuk (top grafting), dan sambung mata tunas (okulasi). Menurut Pramudito et al. (2018), teknik perbanyakan sambung pucuk merupakan yang paling baik. Pendapat tersebut dikuatkan oleh Rukmana (1999) yang menjelaskan bahwa teknik sambung pucuk pada alpokat memiliki tingkat keberhasilan yang tinggi. Teknik sambung pucuk (grafting) dilakukan dengan menyambungkan bagian tanaman dengan bagian lainnya sehingga persenyawaan dapat membentuk tanaman baru. Teknik ini bertujuan untuk memperbaiki sifat bagian atas dan bagian tanaman yang rusak serta mempercepat pembuahan (Hayati et al., 2018). Teknik ini mudah untuk dicoba karena biaya murah, bahan yang dibutuhkan banyak tersedia dan terdapat dalam berbagai bentuk variasi yang disesuaikan dengan jenis tanaman, kondisi batang atas, batang bawah serta lingkungan tempat perbanyakan.

Teknik sambung pucuk dapat dilakukan dengan cara:

1. Siapkan batang bawah dan batang atas. Penyambungan dapat lebih berhasil apabila ukuran batang atas dan bawah sama besar. Apabila ukurannya tidak sama besar, diusahakan salah satu sisinya bertaut

2. Potong entres dengan panjang $5-10 \mathrm{~cm}$ dari batang atas yang memiliki 3 sampai 4 mata tunas kemudian runcingkan bagian pangkalnya

3. Potong bagian bawah, kemudian belah dengan panjang $2-2,5 \mathrm{~cm}$ sesuai dengan panjang bagian entres. Sebelum dipotong batang bawah dibersihkan dulu dengan kain sampai bersih
4. Batang atas disisipkan ke dalam batang bawah, kemudian ikat dengan erat sambungan tersebut dengan tali plastik dari bawah ke atas

5. Sisa batang atas dari ikatan sambungan kemudian dililiti plastik lagi namun usahakan jangan sampai menutupi mata tunas dan disungkup. Setelah disungkup, maka sungkupan di bawah sambungan diikat lagi untuk mengurangi penguapan dan air tidak masuk

6. Letakkan tanaman di tempat teduh dan setelah beberapa minggu dapat dipindah ke tempat yang terik

7. Setelah 2-3 minggu maka sambungan yang berhasil akan tumbuh daun dan tunas baru sedangkan apabila gagal, maka batang atas akan terlihat busuk

8. Setelah sambungan dipastikan berhasil maka bukalah sungkupan supaya tunas dapat tumbuh dengan baik. Selanjutnya bukalah ikatan sambungan yang sudah menyatu. Perawatan dapat dilakukan dengan penyiraman secara teratur

Teknik sambung pucuk (grafting) dikatakan berhasil apabila terjadi pertumbuhan batang bawah. Keuntungan dari batang bawah asal benih (semai) memiliki sistem perakaran yang kuat dan tidak membawa virus dari induknya (Sadwiyanti et al., 2019). Faktor lingkungan, keterampilan sumberdaya manusia dan kecukupan cadangan makanan pada entris dapat mempengaruhi keberhasilan dalam memproduksi bibit dengan menggunakan metode grafting. Pemeliharaan bibit hasil sambung pucuk terutama dalam hal pemupukan harus dilakukan secara intensif.

Pemupukan dengan menggunakan bahan organik dapat dikatakan terbilang murah, mudah didapat serta sifatnya ramah lingkungan. Penggunaan limbah padat ternak sapi yang tersedia melimpah di Kelompok Tani Rukun Makaryo dapat dimanfaatkan dalam budidaya alpokat sehingga dapat menekan penggunaan pupuk kimia sekecil mungkin. Untuk mempercepat proses fermentasi limbah padat ternak sapi tersebut, dilakukan penyiraman biostarter pada limbah padat yang telah disiapkan sebagai pupuk organik padat. Penggunaan mikroorganisme lokal (MOL) dapat mempercepat pembuatan pupuk organik padat fermentasi (Setiawan, 2010). Bahan baku pembuatan biostarter disajikan pada tabel 1 . 
Tabel 1. Bahan Pembuatan Biostarter

\begin{tabular}{clcl}
\hline No & \multicolumn{1}{c}{ Bahan } & Jumlah $(\mathrm{kg})$ & \multicolumn{2}{c}{ Cara Pembuatan } \\
\hline 1 & Rumen Sapi & $10 \mathrm{~kg}$ & Siapkan gentong tertutup kapasitas 20-25 liter. \\
2 & Bekatul & $5 \mathrm{~kg}$ & Siapkan kunir, kecambah, lengkuas, kencur sesuai \\
3 & Kecambah & $5 \mathrm{~kg}$ & dengan kebutuhan kemudian dihaluskan. Semua \\
4 & Kunir & $1-2,5 \mathrm{~kg}$ & bahan dimasukkan dalam gentong yang telah \\
5 & Tetes Tebu & $1 \mathrm{liter}$ & disiapkan kemudian difermentasi selama 10-15 hari. \\
6 & Jahe & $1 \mathrm{~kg}$ & \\
7 & Lengkuas & $1 \mathrm{~kg}$ & Mengingat selama proses fermentasi dapat \\
8 & Kencur & $1 \mathrm{~kg}$ & menghasilkan bau tidak sedap dan menyengat, maka \\
9 & Air Leri (air & 10 liter & dapat ditambahkan buah aroma seperti pepaya, \\
& cucian beras) & & pisang, nanas, tomat, markisa atau sukun yang sudah \\
10 & Air Kelapa & 5 liter & masak secukupnya agar tidak berbau menyengat. \\
\hline
\end{tabular}

Sumber : Data Primer (2020)

Proses pembuatan pupuk organik fermentasi dilakukan dengan menyiapkan limbah padat kotoran ternak sapi yang akan dijadikan pupuk organik fermentasi. Jika masih terdapat sisa-sisa jerami padat, sebaiknya dilakukan pencacahan terlebih dahulu dengan mesin pencacah jerami. Kegiatan proses pembuatan pupuk organik fermentasi disajikan pada Gambar 2.

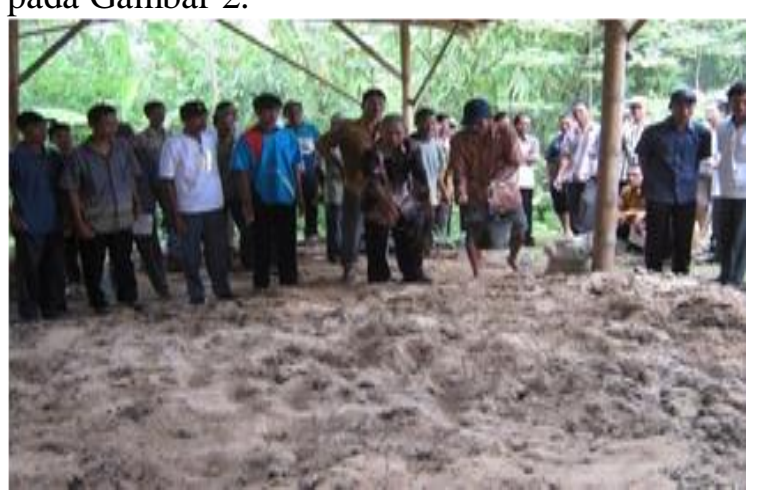

Gambar 2. Proses Pembuatan Pupuk Organik Fermentasi

Pembibitan sebaiknya menggunakan media yang mengandung kecukupan hara, bebas dari gulma dan patogen, tanah mempunyai keasaman yang optimal serta daya tahan air yang baik. Adapun mekanisme penanaman yang disarankan antara lain: (1) Persiapkan lubang tanam sesuai dengan ukuran yang sudah disebutkan; (2) Lubang tanam tersebut kemudian dibiarkan terlebih dahulu selama satu atau dua minggu agar gas-gas yang terdapat di dalam lubang tersebut hilang; (3) Kemudian pada dasar lubang tersebut terlebih dahulu ditaburi pupuk organik sekitar $2 \mathrm{~kg}$ sampai $3 \mathrm{~kg}$. Setelah lubang tersebut didiamkan selama satu atau dua minggu, baru dilakukan pemindahan tanaman alpokat dari polibag ke dalam lubang tersebut. Selanjutnya, lakukan penyiraman secukupnya agar terdapat media untuk menampung unsur hara. Jika sudah mulai tumbuh, maka di sekitar bawah tajuk tanaman secara melingkar perlu ditaburi pupuk organik yang sudah difermentasi.

Kegiatan penyuluhan mengenai teknik budidaya alpokat pada Kelompok Tani Rukun Makaryo melibatkan partisipasi anggota. Peserta mulai muncul kesadaran mengenai pentingnya kegiatan ini. Hal tersebut dapat terlihat dari keaktifan selama proses diskusi. Suasana diskusi yang berlangsung antara tim pengabdian dengan anggota Kelompok Tani Rukun Makaryo pada kegiatan penyuluhan tercermin pada Gambar 3.

Sebagaimana dituturkan oleh Pak Suwardi :

"Masyarakat sudah menanam alpokat tetapi tidak pernah dipupuk, sehingga hanya dibiarkan tumbuh alami begitu saja. Dengan adanya sosialisasi seperti ini membuat masyarakat menjadi antusias."

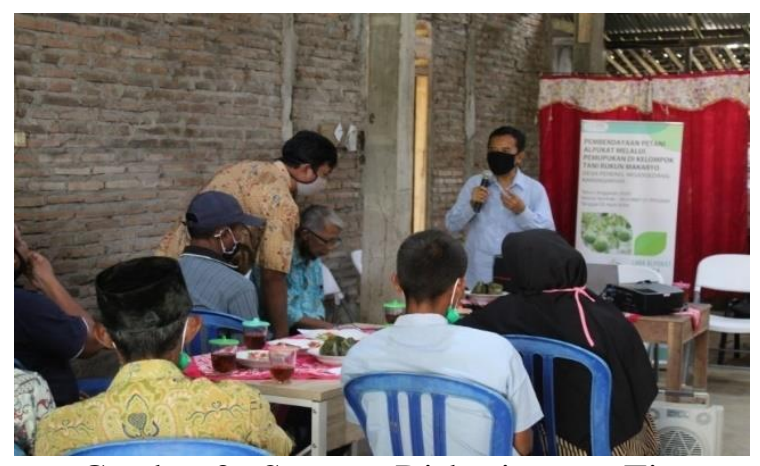

Gambar 3. Suasana Diskusi antara Tim Pengabdian dengan Anggota Kelompok Tani Rukun Makaryo

Pengalaman Bapak Sutardi dalam budidaya alpokat yang dilakukan : 
"Saya menanam alpokat sudah lima tahun ini, sekarang sudah berbuah. Namun, dalam budidaya dari dulu tidak pernah menggunakan pupuk organik. Hanya dilakukan secara alami, tanpa penggunaan perangsang buah sama sekali. Dengan adanya informasi dari video budidaya alpokat yang tadi sudah diputar, dapat menambah pengetahuan mengenai teknik budidaya alpokat secara baik."

Pengalaman Pak Agus dalam menanam alpokat disampaikan sebagai berikut :

"Saya menanam alpokat di depan rumah. Dari mulai saya menanam tidak pernah hidup. Daun tanaman banyak yang kering."

Berdasarkan hasil diskusi, dihasilkan penyelesaian masalah yang biasa dialami anggota kelompok seperti pupuk organik padat yang digunakan adalah limbah ternak sapi yang masih segar dan belum dilakukan fermentasi, sehingga dalam media perakaran terjadi peningkatan panas dan menyebabkan akarnya menjadi mati. Masalah lain yang sering dialami anggota kelompok dalam budidaya alpokat yaitu pada ujung batang yang masih muda dipenuhi dengan serangga berwarna putih yang sering disebut kutu putih atau kutu kebul. Kutu putih atau kutu kebul ini kebanyakan menetap dibagian tangkai muda atau di bagian belakang daun. Dari hasil penelusuran diduga lokasi atau tempat penanamannya lembab. Cara mengatasi kutu putih tersebut sebenarnya cukup sederhana yaitu dengan cara disemprot dengan air yang dicampur sabun cair. Agar tanaman alpokat dapat tumbuh dengan baik, maka pengelolaan tanaman alpokat menjadi penting untuk diperhatikan. Hama yang menyerang tanaman alpokat bervariasi setiap musim sehingga dapat menurunkan produktivitas (Peterson \& Orden, 2008). Apabila tanaman alpokat diserang oleh hama penyakit, maka perlu diatasi dengan menggunakan insektisida organik yang dapat dibuat sendiri menggunakan beberapa jenis tanaman atau buah-buahan yang rasanya pahit di sekitar lingkungan di pedesaan seperti daun paitan, daun tembakau, kulit batang pohon kamboja, buah mahoni yang dicampur dengan air dan kemudian difermentasi. Sepeninggal pembina gapoktan, kondisi dan kegiatan pada Kelompok Tani Rukun Makaryo semakin menurun, maka perlu adanya pendampingan dari pihak eksternal. Sebagaimana dituturkan oleh Pak Suwardi :
"Sesudah ketua kelompok tani mbah Paiman meninggal dunia, anggota kelompok tani kehilangan semangat dalam menjalankan kegiatan kelompok. Untuk itu kami minta bantuan dalam pendampingan agar semangat dalam kegiatan kelompok tani tetap terjaga."

Proses pemberdayaan masyarakat tidak dapat dibatasi dengan waktu yang singkat (Qodriyatun, 2013). Pemberdayaan masyarakat tidak dapat terjadi dalam seketika, melainkan memerlukan waktu yang lama. Rendahnya tingkat partisipasi perlu ditingkatkan dengan mengajak petani untuk lebih aktif terlibat dalam kegiatan kelompok (Winata \& Yuliana, 2012). Hal tersebut dapat dilakukan dengan pendekatan persuasif agar lebih sering menghadiri rapat kelompok, sehingga materi yang disampaikan dapat memotivasi petani. Berakhirnya suatu kegiatan pemberdayaan masyarakat ditandai dengan telah terinternalisasinya inovasi yang disosialisasikan menjadi satu bagian dalam pola perilaku kehidupan masyarakatnya. Adanya modal sosial berupa norma-norma, jaringan dalam kesamaan kultur dan budaya serta kepercayaan dapat melandasi dalam munculnya partisipasi (Hadi, 2014). Apabila petani merasakan keuntungan dari kegiatan tersebut maka timbul kepuasan sehingga partisipasi petani akan terus berlangsung (Putri et al., 2019). Hal ini berkaitan dengan adanya edukasi pengembangan budidaya alpokat pada Kelompok Tani Rukun Makaryo yang dapat meningkatkan kemampuan kelompok sehingga produktivitas meningkat dan menambah pendapatan masyarakat.

Kegiatan edukasi berupa penyuluhan, demonstrasi cara, pemutaran video serta diskusi dengan melibatkan partisipasi anggota dapat berjalan dengan baik. Hal tersebut dapat diketahui dari adanya peningkatan sikap, pengetahuan, dan keterampilan yang ditandai dengan terjawabnya pertanyaan oleh peserta pada sesi diskusi serta sebanyak 70\% (21 orang) sudah menerapkan budidaya alpokat secara tepat pada kunjungan lahan. Pada saat kegiatan monitoring dilakukan, petani sudah menggunakan teknik sambung pucuk dalam penanaman alpokat, membuat biostarter dan menggunakan pupuk organik dalam budidaya alpokat. Proses pendampingan dan monitoring perawatan tanaman alpokat disajikan pada Gambar 4. 


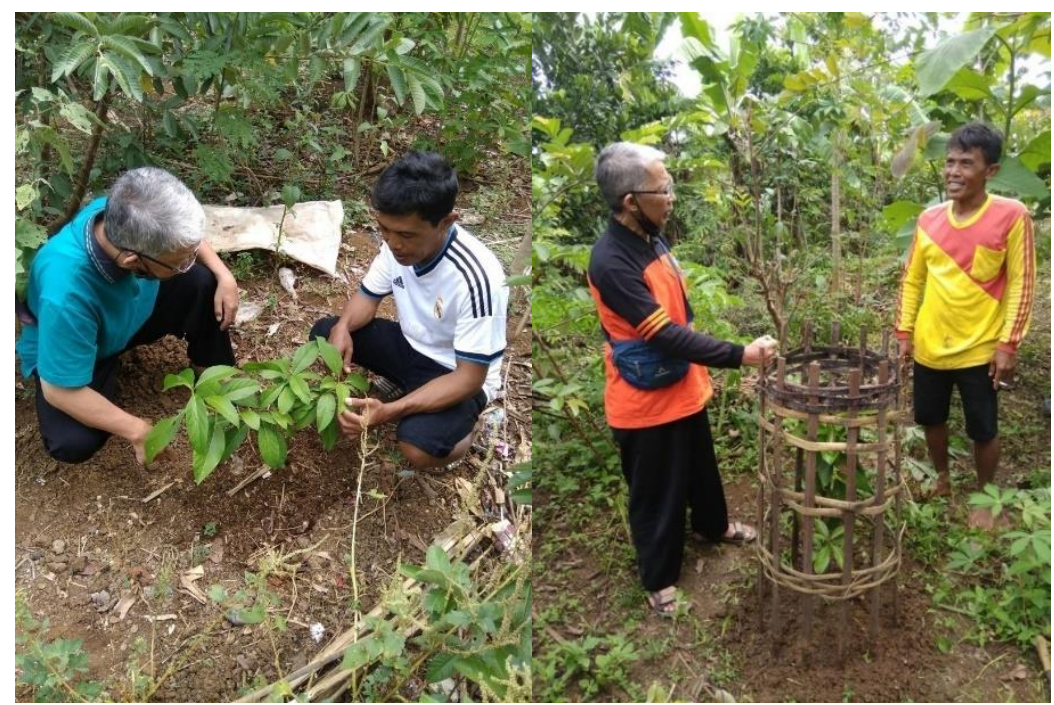

Gambar 4. Pendampingan dan Monitoring

\section{KESIMPULAN}

Pemberian edukasi penyuluhan melalui sosialisasi teknik budidaya alpokat, pemutaran video prospek budidaya alpokat, demonstrasi cara teknik pembiakan vegetatif dengan sambung pucuk (top grafting), serta pembuatan biostarter untuk mempercepat proses fermentasi limbah padat ternak sapi dapat meningkatkan pengetahuan, sikap, dan keterampilan anggota Kelompok Tani Rukun Makaryo. Kegiatan edukasi dapat meningkatkan kemampuan petani dalam membuat pupuk organik padat fermentasi dengan tepat. Anggota Kelompok Tani Rukun Makaryo lebih merasa percaya setelah melihat pemutaran video prospek budidaya alpokat oleh pengusaha bibit alpokat yang sudah berhasil. Bibit alpokat diberikan pada anggota kelompok tani agar dapat ditanam di lahan masing-masing. Hasil akhir pada kegiatan ini adalah anggota Kelompok Tani Rukun Makaryo dapat memperoleh pemahaman mengenai teknik budidaya alpokat secara tepat sehingga dapat mengatasi permasalahan yang dialami selama ini.

\section{UCAPAN TERIMA KASIH}

Penulis menyampaikan terima kasih kepada Universitas Sebelas Maret yang telah memberikan dana hibah PNPB pengabdian masyarakat melalui Surat Perjanjian Nomor 453/UN27.21/KP/2020, sehingga kegiatan Tri Dharma Perguruan Tinggi khususnya pengabdian masyarakat dapat terlaksana dengan baik. Penulis juga menghaturkan terima kasih kepada Rektor Universitas Sebelas Maret yang telah mendorong Civitas Akademik utuk melaksanakan Tri Dharma Perguruan Tinggi dalam bidang pengabdian kepada masyarakat menggunakan dana hibah PNPB UNS, Ketua Lembaga Penelitian dan Pengabdian Masyarakat yang telah memberikan ijin kepada kami untuk penggunaan dana hibah pengabdian PNPB UNS Tahun Anggaran 2020, Ketua Kelompok Tani Rukun Makaryo beserta semua pengurus dan anggotanya yang telah menerima kami dengan sangat hangat, sehingga kegiatan ini dapat terlaksana dengan sukses.

\section{DAFTAR PUSTAKA}

Ainina, I. A. (2014). Pemanfaatan media audio visual sebagai sumber pembelajaran sejarah. Indonesian Journal of History Education, 3(1), 40-45.

Alviana, E., Pujiana, T., Arianti, D., \& Yanfika, H. (2019). Komunikasi penerapan sistem jajar legowo di Desa Murni Jaya Kecamatan Tumijajar Kabupaten Tulang Bawang Barat. Mimbar Agribisnis, 5(2), 156-164.

Amanah, S. (2007). Makna penyuluhan dan transformasi perilaku manusia. Jurnal Penyuluhan, 3(1), 63-67.

Anova, I. T., \& Kamsina, K. (2013). Efek perbedaan jenis alpukat dan gula terhadap mutu selai buah. Jurnal Litbang Industri, 3(2), 91-99.

Araújo, R. G., Rodriguez-Jasso, R. M., Ruiz, H. A., Pintado, M. M. E., \& Aguilar, C. N. (2018). Avocado by-products: Nutritional and functional properties. Trends in Food Science and Technology, 80, 51-60. 
Hadi, S. (2014). Profil modal sosial dan tingkat partisipasi peternak pada pengembangan sapi potong di Kabupaten Tebo Propinsi Jambi. Jurnal Ilmu Komunikasi, 2(2), 107-122.

Hayati, P. K. D., Efendi, S., \& Irawan, R. (2018). Diseminasi teknologi sambung pucuk pada alpukat giri maju di Kabupaten Pasaman Barat. LOGISTAJurnal Ilmiah Pengabdian Kepada Masyarakat, 2(2), 25-31.

Malangngi, L., Sangi, M., \& Paendong, J. (2012). Penentuan kandungan tanin dan uji aktivitas antioksidan ekstrak biji buah alpukat (Persea americana Mill.). Jurnal MIPA, 1(1), 5-10.

Muchtar, K., Purnaningsih, N., \& Susanto, D. (2014). Komunikasi partisipatif pada sekolah lapangan pengelolaan tanaman terpadu (SL-PTT). Jurnal Komunikasi Pembangunan, 12(2), 1-14.

Peterson, E. B., \& Orden, D. (2008). Avocado pests and avocado trade. American Journal of Agricultural Economics, 90(2), 321-335.

Pramudito, P., Fuskhah, E., \& Sumarsono, S. (2018). Efektivitas penambahan hormon auksin (IBA) dan sitokinin (BAP) terhadap sambung pucuk alpukat (Persea Americana Mill). Jurnal Agro Complex, 2(3), 248-253.

Putri, C. A., Anwarudin, O., \& Sulistyowati, D. (2019). Partisipasi petani dalam kegiatan penyuluhan dan adopsi pemupukan padi sawah di Kecamatan Kersamanah Kabupaten Garut. Jurnal Agribisnis Terpadu, 12(1), 103-119.
Qodriyatun, S. N. (2013). Peningkatan kesejahteraan masyarakat pesisir di Kota Batam melalui pemberdayaan masyarakat. Jurnal Aspirasi, 4(2), 91-100.

Rukmana, R. (1999). Teknik memproduksi bibit unggul tanaman buah-buahan. Yogyakarta: Kanisius.

Sadono, D. (2008). Pemberdayaan petani: paradigma baru penyuluhan pertanian di Indonesia. Jurnal Penyuluhan, 4(1), 6574.

Sadwiyanti, L., Sudarso, D., \& Budiyanti, T. (2019). Budidaya alpukat. Sumatera Barat: Balai Penelitian Tanaman Buah Tropika.

Setiana, L. (2005). Teknik penyuluhan dan pemberdayaan masyarakat. Bogor: Ghalia Indonesia.

Setiawan, B. S. (2010). Membuat pupuk kandang secara cepat. Jakarta: Penebar Swadaya.

Utama, S., Sumardjo, S., Susanto, D., \& Gani, D. S. (2010). Dinamika kelompok tani hutan pada pengelolaan hutan produksi bersama masyarakat di perum perhutani unit I Provinsi Jawa Tengah. Jurnal Penyuluhan, 6(1), 49-64.

Winata, A., \& Yuliana, E. (2012). Tingkat partisipasi petani hutan dalam program pengelolaan hutan bersama masyarakat (PHBM) perhutani. MIMBAR: Jurnal Sosial Dan Pembangunan, 28(1), 65-76.

Yunasaf, U., \& Tasripin, D. S. (2011). Peran penyuluh dalam proses pembelajaran peternak sapi perah di KSU Tandangsari Sumedang. Jurnal Ilmu Ternak Universitas Padjadjaran, 11(2), 98-103. 